\title{
EFFECT OF DEMAND UNCERTAINTY ON COST STRUCTURE OF TURKISH MANUFACTURING FIRMS
}

\author{
Hakan ÖZKAYA ${ }^{1}$
}

Umut UYAR ${ }^{2}$

\begin{abstract}
Cost rigidity defines the characteristics of cost structure which is defined as the proportion of fixed costs to variable costs of firms. When the proportion of fixed costs are higher than the variable costs, then the cost structure is defined as a rigid cost structure. The structure of operating costs of Turkish manufacturing firms between years 1995 and 2014 is tested in terms of their "rigidity" in this paper. Moreover, the effect of demand uncertainty, as measured by the standard deviation of net sales, on the cost structure of operating costs is also tested. Findings support that higher levels of demand uncertainty are associated with higher portions of fixed costs in the cost structure (i.e., more rigid cost structure). That result contradicts the common wisdom that firms tend to lower the fixed costs in their cost structure as they are confronted with uncertainty.
\end{abstract}

Keywords: Cost structure, cost rigidity, demand uncertainty, cost behavior

JEL Classification: M41, M48

\section{TALEP BELIRSIZLIĞiNIN TÜRK IMALAT FIRMALARININ MALIYET YAPISI ÜZERINDEKI ETKISI}

\begin{abstract}
Öz
Maliyet katılığı işletmelerin sabit maliyetlerinin değişken maliyetlerine oranı olarak tanımlanan maliyet yapısının özelliğini betimlemektedir. İşletmelerin sabit maliyetlerinin oranının, değişken maliyetlerinden daha yüksek olması durumunda katı bir maliyet yapısından söz edilir. Bu çalışmada, Türkiye'de 1995-2014 döneminde faaliyet gösteren halka açık imalat firmalarının, faaliyet giderlerinin yapısı "maliyet katılığı" kavramı açısından incelenmektedir. Analizlerde net satışların standart sapması ile hesaplanan talep belirsizliğinin, faaliyet giderlerinin maliyet yapısı üzerine olan etkisi de ayrıca test edilmiştir. Analiz sonuçlarına göre maliyet yapısı içerisinde sabit maliyetlerin oranının artmasının ya da daha katı maliyet yapısının, imalat firmaları için daha fazla talep belirsizliği kaynaklı olduğu tespit edilmiştir. Bu sonuç, firmaların belirsizliklerle karşı karşıya kaldıkları durumda sabit maliyetlerini düşürme eğiliminde olduklarını ifade eden genel teorik beklentiyle çelişmektedir.
\end{abstract}

Anahtar Kelimeler: Maliyet yapısı, maliyet katılığı, talep belirsizliği, maliyet davranışı JEL SInıflandırması: M41, M48

${ }^{1}$ Assistant Prof. Dr., Dokuz Eylül University, Izmir, Turkey, hakanozkaya@gmail.com, ORCID: 0000-0001-7810-5943

${ }^{2}$ Assistant Prof. Dr., Pamukkale University, Denizli, Turkey, uuyar@pau.edu.tr, ORCID: 0000-0001-6217-8283 


\section{Introduction}

Understanding cost structure is one of the crucial topics in management accounting. Because it is the cost structure to determine the cost behavior and affect nearly all performance measures like profitability of companies. Banker and Byzalov (2014) claim that understanding the cost structure and asymmetric cost behavior constitutes a new way of thinking not only about costs but also about earnings. Hence understanding the cost structure is one of the main pillars of budgeting.

It is posited in cost accounting textbooks that firms which have a higher portion of fixed costs in their cost structure (i.e., more rigid cost structure, less elastic cost structure) are more vulnerable to losses due to lower contribution margins and higher breakeven points (Horngren et al. 2012). This implies that firms that are confronted with uncertainty would choose more elastic cost structure to avoid possible losses due to a decrease in sales. However, this textbook knowledge out of intuition needs to be checked as stated by many authors (Banker, Byzalov and PlehnDujowich, 2014). Many attempts have been made to unravel the topic. This paper is merely one of them which tries to shed light on understanding the cost structure of Turkish manufacturing firms and on understanding the relationship between uncertainty and cost structure.

The aim of this paper is to examine the effect of demand uncertainty on the cost structure of Turkish firms. 147 Turkish manufacturing firms', from 13 industries, financial statements data are analyzed between 1995 and 2014. In the framework of cost rigidity literature, uncertainty variables are included in different models as interaction terms for presenting the mediating effect of demand uncertainty on the cost structure. Due to the panel structure of data, models are estimated by using panel data techniques.

Although the cost structure is an important issue in understanding cost behavior of Turkish manufacturing firms, no study was conducted about Turkish firms on this topic in the literature. Understanding the cost structure and hence cost behavior of manufacturing firms is even more important for countries like Turkey as it has experienced many economic crises or at least instabilities in terms of revenue streams. This paper will be the first to relate cost structure of manufacturing firms and demand uncertainty for Turkish firms.

The theory of cost structure is quite clear and simple but there have always been some limitations on the data. Financial variables used in the analysis are subject to the impact of severe inflation experienced in Turkey especially in the 1990s. Since our analysis mostly based on differences of variables from one year to another year, the effect of inflation was misleading. We overcame this limitation by deflating all financial variables used in the analysis.

The remainder of the paper proceeds as follows: In the next section, a relevant literature on cost rigidity is summarized. "Methodology and Data" section introduces the model and variables. Also, hypotheses of study are developed and data gathering process is explained in detail in this section. Findings of the analysis are presented in "Results" section and finally "Conclusion" section concludes by summarizing and discussing the results.

\section{Literature Review}

Activity volume-based cost drivers have always been at the heart of cost accounting and costs are assumed to move proportionally to activity volume. That is costs increase as activity volume increase and decrease as the activity volume decrease. Moreover, this increase and decrease based on activity volume are thought to be proportional. One of the earliest work to question the relevance of volume-based cost drivers was carried out by Banker and Johnston (1993). Although their analysis did not aim at testing the proportionality assumption of activity volume and costs, they report that besides volume-based cost drivers, operations-based drivers are also significant in the airline industry. The implicit assumption that overhead costs are strictly proportional to activity volume was first tested by Noreen and Soderstrom (1994). Using cross-sectional data from Washington hospitals, they report that long run overhead costs are not proportional to activity and 
average cost declines with activity. In their following work, Noreen and Soderstrom (1997) examined the time series behavior of overhead costs. They report that very small portion of overhead costs is made up of variable costs (averaging around $20 \%$ for the years examined). This implies that costing systems that assume proportionality are likely to yield higher costs which will shadow the decision making and performance evaluation processes.

Anderson, Banker, and Janakiraman (2003) were the first to name this diversion from proportionality hypothesis as cost stickiness in their work. Since then there is a bunch of literature (i.e. Calleja, Steliaros, and Thomas (2006), Balakrishnan and Gruca (2008), Chen, Lu, and Sougiannis (2012), Banker and Byzalov (2014), Anderson, Lee, and Mashruwala (2016)) examining whether costs present a sticky or anti-sticky behavior. Banker, Basu, Byzalov, and Chen (2016) state in their study that the asymmetry for sales changes is compatible with sticky costs. Cohen, Karatzimas, and Naoum (2017) examined a different sample for cost stickiness: local governments. In their study, they reveal that costs stickiness (anti-stickiness) hypothesis is valid for municipalities in Greece after increases or decreases in the stream of their revenues. Their findings suggest that there is an anti-stickiness cost behavior when revenues decrease. However, they also state that there is a coststickiness behavior after an adjustment on the costs of service provision. Li and Zeng (2017) focus on the operating environment of firms and cost stickiness relation. Their analyses consist of four different findings: (i) there is a strong evidence is that when the determinants of cost stickiness can be controlled, there is an increasing cost asymmetry in the competition. (ii) it can be said that a manager who has more resources for investment expenditures in spite of a sales fall increases the degree of cost stickiness. (iii) if management is optimistic about future demand, the cost stickiness is increasing in competition, and vice versa. (iv) finally, the authors state that the relationship between competition and cost stickiness is more obvious for single-segment firms relative to multisegment firms. Similarly, Lee and Chiang (2018) discuss the topic based on the decision of managers' liability insurance in Taiwan for the period of 2008-2015. The authors documented that the degree of selling, general and administrative cost stickiness increases when the level of managers' insurance coverage arise. Thus, they state that the insurance coverage level can motivate firms' resource commitment decisions.

On the other hand, Banker, Byzalov, and Plehn-Dujowich (2014) contrast the notion of cost stickiness and cost rigidity. While cost stickiness refers to the asymmetric cost behavior reflected as a result of ex-post short-term resource adjustment decisions of managers, cost rigidity reflects the consequences of managers' longer-term capacity choices that are made ex-ante. Likewise, Chen, Jiang, and Zeng (2016) used a large sample of Chinese private firms and they found that selling, general, and administrative costs are on average anti-sticky. Koo, Song, and Paik (2015) studied the effects of incentives for earnings management on the stickiness of selling, general, and administrative expenses. Findings of the study suggest that earnings management suspect firms decrease cost stickiness when faced with declining sales.

The notion that the ratio of variable costs to fixed costs in the cost structure increases as firms face higher uncertainty is also implied by the real option theory. The role of uncertainty in cost behavior was investigated by Kallapur and Eldenburg (2005). Utilizing the real option theory, the authors focused on contribution margin uncertainty and argue that managers would prefer technologies with higher variable costs and lower fixed costs as uncertainty increases. This result is in line with the conventional thought. Liu and Lahiri (2015) investigate the foreign competition and cost asymmetry relation. The findings reveal that cost asymmetry and foreign competition interacts each other in an interesting way. Homburg et. al. (2018) analyze the relationship between different types of asymmetric cost behaviors and credit default swaps. The authors presented that the cost-risk relationship varies depending on whether it is variable or fixed costs. Lee (2018) focused on the asymmetric cost behavior model and constructed two models. The authors' the first result recognizes that costs are determined by various drivers including volume and capacity. It is clear that adding a cost driver to the asymmetric cost behavior model contributes to the 
understanding of cost behavior. The second result of the study is that cost asymmetry varies systematically over the life-cycle periods that follow the value of future revenue adjustments.

Another group of studies focused on profitability and cost asymmetry relationship. Fanti and Meccheri (2017) investigated the profitability and degree of cost asymmetry relationship with respect to Nash equilibrium. The authors found that more efficient firm may receive higher profits given that the degree of cost asymmetry between firms is adequately large. Likewise, Hartlieb and Loy (2016) examined the relationship between cost stickiness and income smoothing. Their results indicate that there is a negative relationship between cost stickiness and income.

Banker et al. (2014) investigated the role of demand uncertainty on cost structure and cost behavior both empirically and analytically. Banker et al. (2014) tested their hypothesis empirically at the firm level and industry level. As they include interaction term which captures the effect of demand uncertainty, slope $\beta$ decreases which reveals that demand uncertainty and cost rigidity have a positive association. Their results show that firms and industries which face more demand uncertainty have a cost structure with higher portions of fixed costs and lower variable costs. One recent research on cost behavior was conducted by Holzhacker, Krishnan and Mahlendorf (2015). Using California hospitals' data, they investigated the effect of demand uncertainty and financial risk on cost behavior. Furthermore, they investigated the mediation effect of three resource procurement choices, namely: outsourcing, leasing, and hiring contract labor, on the cost structure. They conclude that demand uncertainty and financial risk are two important factors determining cost structure and that both of these factors increase the cost elasticity. The results of Holzhacker, Krishnan and Mahlendorf (2015) and Banker et al. (2014) on the association of demand uncertainty and cost elasticity contradict. Holzhacker, Krishnan and Mahlendorf (2015) provide some possible explanations for this discrepancy. One possible explanation is related to peculiar characteristics of hospitals on the extremely severe consequences of congestion (i.e., mortality and morbidity). This causes hospitals to maintain standby or reserve capacity which in turn decreases the congestion costs. Since the presence of congestion costs are said to be the reason why managers chose a more rigid cost structure in case of demand uncertainty, the results for hospitals contradict with those for other industries. The second possible explanation provided by Holzhacker, Krishnan and Mahlendorf (2015) is that managers of the hospitals in their sample are not provided equity incentives. Since equity incentives allow for potentially unlimited gains in case of high demand, it may increase the attractiveness of a more rigid cost structure. It is reported in the literature that customer concentration has also effect on cost elasticity (Chang, Hall and Paz, 2015). As customer concentration increase firms chose a less elastic cost structure (i.e., lower proportions of variable-to-fixed costs). This finding also supports previous results that cost rigidity increases with demand uncertainty if customer concentration can be associated with a relatively uncertain demand when compared to the less concentrated customer base. Another study on the relationship between demand uncertainty and cost behavior is performed by Ibrahim (2015). The data gathered from the Egyptian Stock Exchange for the pre- and post-2008 financial crisis periods. The author examined whether costs respond asymmetrically to demand change. The finding suggests that the relationship between cost behaviors and demand uncertainty differs in times of the prosperity or recession periods.

\section{Methodology and Data}

Banker et al. (2014) set up a cost model of two components: a fixed component, which was decided before the demand, has been observed (ex-ante) and a variable component, which was decided after the demand realization. They argue that firms with higher demand uncertainty have short-run cost structure with higher fixed costs and lower variable costs, which they call as a more "rigid" cost structure. This is caused by the optimal respond of managers on capacity choices to increased demand uncertainty. This argument, of course, seems to contradict with the intuitively held traditional approach that managers would choose a cost structure with lower fixed and higher variable costs in case of facing an uncertainty. Banker et al. (2014) argue that this conventional 
wisdom may hold in the context of increased downside risk but not in the context of demand uncertainty. In the case of demand uncertainty, both exceptionally high and low demands become likely. In the case of exceptionally high demand realizations, fixed inputs will not be sufficient, and congestion cost will be incurred. To relieve this congestion in case of high demand realization, managers need to increase the proportion of fixed input which leads to a more rigid cost structure. In the case of exceptionally low demands, the variable portion of cost structure will shrink, but the fixed portion will remain constant since it was decided before the demand realization. Hence the proportion of fixed input to variable input will be higher leading to again a more rigid cost structure. Thus, we can express our hypotheses as follows:

$\mathbf{H}_{0}$ : Firms have more rigid cost structure as demand uncertainty increases.

Banker et al. (2014) characterize cost behavior in terms of "cost rigidity." They define cost rigidity as the "mix of fixed and variable costs in the short run cost structure of the firm." The degree of cost rigidity is measured by the estimation of the following equation. They argue that logarithmic expression of the variables has some advantages over a linear model like making variables more comparable across firms, alleviating heteroscedasticity and having a clearer economic interpretation. Thus, we continue to follow the log-linear specification used by previous studies.

$$
\Delta \operatorname{lnCOST}_{i, t}=\beta_{1}+\boldsymbol{\beta}_{2} \Delta \operatorname{lnSALES} S_{i, t}+\gamma_{0} \text { controlvariables }_{i, t}+\varepsilon_{i, t}
$$

The slope $b_{2}$ in Equation 1 is the measure of cost rigidity. Since the regression variables are expressed in log changes, $B_{2}$ indicates the percentage change in cost for a $1 \%$ change in sales. Hence; if the $b_{2}$ approaches 0 , then the cost structure is said to be more rigid and if the $B_{2}$ approaches 1 , then the cost structure is said to be less rigid. In the extreme cases; if $B_{2}$ is equal to 0 , the cost structure is comprised of all fixed costs, and if $B_{2}$ is equal to 1 , this implies a cost structure which is comprised of all variable costs. A less rigid short-run cost structure is associated with a greater slope $B_{2}$, where costs are subjected to a change in a greater extent for the same degree of change in sales.

To test the effect of demand uncertainty on the cost structure, we decomposed the slope $B_{2}$ in Equation 1, which is the measure of cost rigidity, by including an interaction variable (uncertainty variable $x \triangle \operatorname{lnSALES}$ ) into Equation 1 . We express Equation 2 as follows:

$$
\begin{aligned}
& \Delta \operatorname{lnCOST}_{i, t}=\beta_{1}+\boldsymbol{\beta}_{2} \Delta \operatorname{lnSALES} S_{i, t}+\boldsymbol{\beta}_{3}^{\omega} \Delta \operatorname{lnSALES} S_{i, t} * U_{N C E R T_{i}}+\gamma_{0} \text { controlvariables }_{i, t}+ \\
& \varepsilon_{i, t}(\omega=1,2,3,4)
\end{aligned}
$$

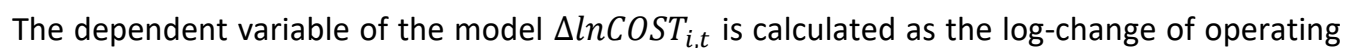
costs for firm $i$, from year $t-1$ to year $t . \Delta \ln S A L E S_{i, t}$ is calculated as log-change of net sales for firm $i$, from year $t-1$ to year $t$. We used deflated operating costs and net sales following prior studies like Anderson et al. (2003), Kallapur and Eldenburg (2005), Banker et al. (2014). Use of deflated values is even more important for studies conducted in countries like Turkey where there had been unstable levels of inflation rates throughout the sample period. So, the impact of inflation on financial variables were removed by deflating all years to 1998 values by using appropriate coefficients of GDP deflator taken from World Bank.

We used four different versions of our uncertainty variable to test and present the mediating effect of demand uncertainty on the cost structure (see Eq.2 for $\omega$ ). Our main uncertainty measure is UNCERTnom. UNCERTnom is the nominal values for each firm demand uncertainty during the sample period and is calculated as the standard deviation of log-changes in sales $\left(\triangle \ln S A L E S_{i, t}\right)$ in the entire sample period. So UNCERTnom is a time-invariant variable and unique to firms in all period. Other uncertainty variables used in our study are derived from UNCERTnom variable. The first derived uncertainty variable is the UNCERTdummy which takes the value of 1 if the UNCERTnom for a specific firm is higher than the average UNCERTnom for the entire sample, 0 otherwise. The second uncertainty variable is UNCERThighQ is a dummy variable which takes the 
value of 1, if a firm's UNCERTnom is in the highest quartile based on the uncertainty of all sample, 0 otherwise. The third uncertainty variable is UNCERTIowQ is also a dummy variable which takes the value of 1 , if a firm's UNCERTnom is in the lowest quartile based on the uncertainty of all sample, 0 otherwise. Our control variable is GDP growth used to capture the macroeconomic effects on the cost structure.

In this model $\beta_{2}$ and $\beta_{3}^{\omega}$ together measures the degree of cost rigidity. In the extreme case when there is no uncertainty, $\beta_{2}+\beta_{3}^{\omega}$ will be equal to $\beta_{2}$, and as $\beta_{3}^{\omega}$ is significant, $\beta_{2}$ will be moderated. Thus, the $\beta_{3}^{\omega}$ will be the focus of interest in our analysis which indicates the effect of demand uncertainty on the cost structure.

After introducing our model and variables, we can modify and reformulate our $\mathrm{H}_{0}$ hypotheses as follows:

$\mathrm{H}_{0 \mathrm{a}}: \beta_{3}^{1}$ is negative when UNCERTnom interacts with $\triangle \operatorname{lnSALES}$ which indicates that firms have more rigid cost structure as demand uncertainty increases.

$\mathrm{H}_{\mathrm{ob}}: \beta_{3}^{2}$ is negative when UNCERTdummy interacts with $\triangle \ln S A L E S$ which indicates that firms have more rigid cost structure as demand uncertainty increases.

$\mathrm{H}_{0 c}: \beta_{3}^{3}$ is negative when UNCERThighQ interacts with $\triangle \ln S A L E S$ which indicates that firms have more rigid cost structure as demand uncertainty increases.

$\mathrm{H}_{\mathrm{dd}}: \beta_{3}^{4}$ is positive when UNCERTlowQ interacts with $\triangle \operatorname{lnSALES}$ which indicates that firms have more rigid cost structure as demand uncertainty increases.

Our sample consists of Turkish manufacturing firms between 1995 and 2014. We went through several elimination procedures. Firstly, since our model requires working with differences from the previous period to current period, firms whose current or lagged operating costs or sales data are missing were discarded for that specific period from the sample. In line with the literature (Banker et al. (2014), Anderson et al. (2003)) firm-year observations which have an operating loss (i.e., operating costs exceed sales) were also discarded. Since our "uncertainty" measure is calculated as the standard deviation of sales, following Banker et al. (2014), we discarded firms with less than ten years of sales data from our sample. Finally, to eliminate the effect of outlier observations on the results, 1 percent of each tail of sample were also discarded. The elimination of outliers enhanced the skewness and kurtosis of variables. The elimination procedure yielded 147 Turkish manufacturing firms from 13 industries through 20 years between 1995 and 2014 and 2.656 firmyear observations. The descriptive statistics are presented in Table 1.

Table 1: Descriptive Statistics

\begin{tabular}{lccccc}
\hline & Mean & Median & Max. & Min. & St.Dev. \\
\hline $\begin{array}{l}\text { Dependent variable } \\
\begin{array}{l}\text { InCOST } \\
\text { Independent variables }\end{array}\end{array}$ & 0.013 & 0.017 & 0.847 & -0.799 & 0.230 \\
$\begin{array}{lllll}\text { InSALES } \\
\text { UNCERTnom }\end{array}$ & 0.002 & 0.015 & 0.732 & -1.074 & 0.240 \\
\hline & 0.273 & 0.225 & 1.127 & 0.100 & 0.162 \\
\hline
\end{tabular}

The dependent variable $\triangle$ InCOST is the log-change of deflated operating costs for firm $\mathrm{i}$, from year $\mathrm{t}-1$ to year $t$. $\triangle$ InSALES is the log-change of deflated net sales for firm i, from year t-1 to year t. UNCERTnom is the standard deviation of log-changes in sales in the entire sample period.

\section{Results}

Considering the panel structure of our data, we estimated our model by using panel data techniques over pooled OLS. Although not reported here, results estimated by pooled OLS did not change the signs and the significance of the coefficients. Fixed effect specification with cross section GLS weights were employed in our regressions to control for firm-specific and timeinvariant factors and depending on the Hausman test results. The Hausman Chi-Square Statistics 
(presented in Table 3) reveal that random effects estimator is inconsistent under the alternative hypothesis, but fixed effects estimator is consistent. We chose fixed effects estimator in this circumstance.

We tested whether our models would suffer from heteroscedasticity and autocorrelation problems or not. Table 2 presents test results for heteroscedasticity (Panel A) and autocorrelation (Panel B). According to the diagnostic test results, both heteroscedasticity and autocorrelation are prevalent for all models. To overcome this problem, the EGLS estimator (using cross section weights) is employed. The EGLS estimator which is suggested by Baltagi $(2005: 22,82)$ is robust to heteroscedasticity and autocorrelation in panel data models.

Table 2: Heteroskedasticity and Autocorrelation Test Statistics for Models

\begin{tabular}{|c|c|c|c|c|c|}
\hline Panel A & Model 0 & Model 1 & Model 2 & Model 3 & Model 4 \\
\hline$\chi^{2}(147)$ & $3,207.63$ & $2,924.04$ & $3,023.72$ & $3,024.66$ & $2,986.85$ \\
\hline $\operatorname{Prob}>\chi^{2}$ & 0.0001 & 0.0001 & 0.0001 & 0.0001 & 0.0001 \\
\hline
\end{tabular}

Modified Wald test for group wise heteroscedasticity in fixed effect regression model. $\mathrm{H}_{0}: \sigma_{i}^{2}=\sigma^{2}$ for all $i$

\begin{tabular}{lllllll}
\hline Panel B & & Model 0 & Model 1 & Model 2 & Model 3 & Model 4 \\
\hline & $F(1,146)$ & 2.534 & 2.108 & 2.026 & 2.279 & 1.535 \\
& $P r o b>F$ & 0.1136 & 0.1487 & 0.1568 & 0.1333 & 0.2174 \\
\hline
\end{tabular}

Wooldridge test for autocorrelation in panel data. $\mathrm{H}_{0}$ : No first order autocorrelation

In Model 0 , the log-change of deflated net sales ( $\triangle$ InSALES) is regressed against the logchange of deflated operating costs $(\Delta \mathrm{InCOST})$ and the control variable GDP growth was also included. This model is used to test the cost structure of the firms in the sample. In other words, how much "rigid" is the operating costs of the firms is tested by this model. As stated earlier, the coefficient $\beta_{2}$ of 1 would imply a cost structure comprised of completely variable costs, and the coefficient of $\beta_{2} 0$ would imply a completely rigid cost structure where operating costs do not change as activity level changes. Results show that $\beta_{2}$ is equal to 0.45 which indicates that a $1 \%$ change in the sales results in an average of $0.45 \%$ change in operating costs in the same direction.

The main aim of this study is to test the effect of demand uncertainty on the cost structure of firms. Thus, uncertainty variables are included in the models as interaction terms. Model 1 tests the main hypotheses that cost structure becomes more rigid as the demand uncertainty increase. The significantly negative coefficient of $\beta_{3}^{1}$ of -0.248 ( $t$ statistics -2.829 ) for the interaction term supports our hypotheses.

For a clearer economic interpretation of $\beta_{3}^{1}$, we used dummy versions of uncertainty measure in the interaction term. In the model 2 , the above uncertainty average firms took the value of 1 and the below uncertainty average took the value of 0 . The $\beta_{3}^{2}$ coefficient of -0.060 ( $t$ statistics 1.999) indicates a more rigid cost structure for firms having higher demand uncertainty. Firms with higher demand uncertainty have $\% 6$ percent more rigid cost structure. In other words, the rigidity measure of the equation (i.e., $\beta_{2}+\beta_{3}^{\omega}$ ) on average takes the value of 0.41 for firms with higher demand uncertainty, and it takes the value of 0.47 for firms with lower demand uncertainty. The $\beta_{3}^{3}$ and $\beta_{3}^{4}$ coefficients of model 3 and model 4 can be interpreted in the same way. The $\beta_{3}^{3}$ of 0.069 ( $t$ statistics -2.262 ) in model 3 indicate that firms with demand uncertainty in the upper quartile have $7 \%$ more rigid cost structure. Likewise, the $\beta_{3}^{4}$ coefficient of model 4 which is 0.073 ( $t$ statistics 1.860 ) indicates that firms with demand uncertainty in the lower quartile have $7 \%$ less rigid cost structure than the rest of the sample. 
Table 3: Estimation Results

\begin{tabular}{|c|c|c|c|c|c|}
\hline Variables & Model 0 & Model 1 & Model 2 & Model 3 & Model 4 \\
\hline \multicolumn{6}{|l|}{ Dependent Variable } \\
\hline \multicolumn{6}{|l|}{$\Delta \operatorname{lnCOST}$} \\
\hline \multicolumn{6}{|l|}{ Independent Variables } \\
\hline \multirow[t]{2}{*}{ Intercept } & 0.003 & 0.002 & 0.003 & 0.003 & 0.003 \\
\hline & $(0.717)$ & (0.579) & $(0.622)$ & $(0.631)$ & $(0.736)$ \\
\hline \multirow[t]{2}{*}{$\triangle \operatorname{lnSALES}$} & 0.447 & 0.526 & 0.471 & 0.471 & 0.437 \\
\hline & $(29.346)^{* * *}$ & $(16.936)^{* * *}$ & $(24.511)^{* * *}$ & $(25.446)^{* * *}$ & $(26.607)^{* * *}$ \\
\hline \multirow[t]{2}{*}{$\triangle$ InSALES*UNCERTnom } & & -0.248 & & & \\
\hline & & $(-2.829)^{* * *}$ & & & \\
\hline \multirow[t]{2}{*}{$\triangle$ InSALES*UNCERTdummy } & & & -0.060 & & \\
\hline & & & $(-1.999)^{* *}$ & & \\
\hline \multirow[t]{2}{*}{$\triangle$ InSALES*UNCERThighQ } & & & & -0.069 & \\
\hline & & & & $(-2.262)^{* *}$ & \\
\hline \multirow[t]{2}{*}{$\triangle$ InSALES*UNCERTlowQ } & & & & & 0.073 \\
\hline & & & & & $(1.860)^{*}$ \\
\hline \multirow[t]{2}{*}{ GDPgrowth } & 0.229 & 0.222 & 0.225 & 0.228 & 0.219 \\
\hline & $(3.139)^{* * *}$ & $(3.027)^{* * *}$ & $(3.074)^{* * *}$ & $(3.109)^{* * *}$ & $(2.988)^{* * *}$ \\
\hline Adjusted R-Square & 0.295 & 0.299 & 0.296 & 0.295 & 0.296 \\
\hline Number of Observations & 2656 & 2656 & 2656 & 2656 & 2656 \\
\hline Number of Clusters & 147 & 147 & 147 & 147 & 147 \\
\hline Hausman Test Chi-Sq. Statistics & $8.506 * *$ & $9.358 * *$ & $8.575^{* *}$ & $8.212^{* *}$ & $8.517^{* *}$ \\
\hline \multicolumn{6}{|c|}{$\begin{array}{l}\text { Equation of } \triangle \operatorname{lnCOST} T_{i, t}=\beta_{1}+\boldsymbol{\beta}_{2} \Delta \operatorname{lnSALES} S_{i, t}+\boldsymbol{\beta}_{3}^{\omega} \triangle \operatorname{lnSALE} \\
\text { estimated by using fixed effects with cross section GLS weights ( } \omega \\
\text { log-change of deflated operating costs for firm i, from year t- } 1 \text { to } \\
\text { sales for firm i, from year } \mathrm{t}-1 \text { to year t. UNCERTnom is the stand } \\
\text { sample period. UNCERTdummy takes the value of } 1 \text { if the UNCER } \\
\text { UNCERTnom for the entire sample, } 0 \text { otherwise. UNCERThighQ ta } \\
\text { highest quartile based on the uncertainty of all sample, } 0 \text { otherv } \\
\text { UNCERTnom is in the highest quartile based on the uncertainty of } \\
* \text { Significance at the } 10 \% \text { level using a one-tailed test. } \\
* * \text { Significance at the } 5 \% \text { level using a one-tailed test. } \\
* * * \text { Significance at the } 1 \% \text { level using a one-tailed test. }\end{array}$} \\
\hline
\end{tabular}

\section{Conclusion}

The structure of cost behavior under the uncertainty is an important topic to understand. In traditional cost behavior theory, costs change symmetrically in response to upward and downward changes in their factors. However, the behavior of cost is not always symmetrical and proportional. When managers face a decrease in sales relative to previous period sales, they have to decide on cutting some resources to avoid the cost of unused capacity, or not. On that point, if future sales rebound, these resources will be needed. So, every decision has an adjustment cost. Hence, there is evidence that most cost items change asymmetrically in response to upward changes and downward changes in activities driving them (Abdulhamied and Abulezz, 2016). Banker, et al. (2014) analyses show that firms and industries which face more demand uncertainty have a cost structure with higher portions of fixed costs and lower variable costs. 
The motivation of this study is to understand the cost structure under uncertainty circumstances for a sample of Turkish manufacturing firms. Although the cost structure is a critical issue in understanding cost behavior of Turkish manufacturing firms, no study was conducted about Turkish firms on this topic in the literature. For this purpose, 147 Turkish manufacturing firms' financial statements are used between 1995 and 2014. Five different models are derived from varying perspectives of demand uncertainty effect on the cost structure. Due to the panel structure of data, models are estimated by using panel data techniques. Fixed effect specification with cross section GLS weights was employed in all regressions.

The primary findings indicate that a one percent change in the sales results in an average of $0.45 \%$ change in operating costs in the same direction. This result emphasizes that the elasticity of operating costs is low because the coefficient of sales variable is lower than one. The main aim of this study was to examine the effect of demand uncertainty on the cost structure of firms. Therefore, the uncertainty variables are included in different models as interaction terms. The estimation results show that when the demand uncertainty increases, cost structure becomes more rigid, additionally; firms with higher demand uncertainty have $\% 6$ percent more rigid cost structure. While firms with demand uncertainty in the upper quartile have $7 \%$ more rigid cost structure, firms with demand uncertainty in the lower quartile have $7 \%$ less rigid cost structure than the rest of the sample.

Our results are in line with the results of Banker, et al. (2014) and Atasoy, Banker and Byzalov (2014). Our results confirm that; as demand uncertainty increases, managers chose to increase their firms' capacity commitments of fixed activity resources due to the presence of significant congestion costs. This means that on average managers tend to preserve their production capacities in case of demand uncertainty. Managers should be aware of this fact that if they decrease their capacity upon immediate demand uncertainty cases, their companies' middle and long-term competition power in terms of production capacity may be jeopardized. Managers should interpret the results indicating that greater demand uncertainty leads to a more rigid cost structure cautiously. Here it should be noted that demand uncertainty as measured by this paper has no power to shed light on the direction of the risk. If the direction of the risk is downwards, the implications of this paper may not hold. Thus managers should be very well aware of the distinction between very much alike but different phenomena like uncertainty and downside risk. They should be able to interpret variation with its direction and take appropriate actions. Future research shall incorporate the effect of downside and upside risks on the cost structure of firms.

When being evaluated together with results of Irvine, Park and Yıldızhan (2016) who report that customer-base concentration (which is one of the sources of demand uncertainty) affects the profitability adversely in the early years of relationship but as relationship matures its effect on profitability turns to be positive, our results have further implications for managers. Managers of the firms, which have the opportunity to make long-term business agreements with some large scale customers should be prepared to incur some decrease in short term profitability (or even losses) due to increase in proportion of fixed costs in their cost structure.

Results have also implications for board members and top management who evaluate managerial performance in their companies. While evaluating the performance of managers who are experiencing demand uncertainties, increase in fixed costs and decrease in profit margins should be evaluated with tolerance. Increase in fixed costs in the short run may lead to abnormal future profits.

\section{References}

Abdulhamied, A. A. and Abulezz, M. E. (2012). An Empirical Investigation of the Effect of Cost Structure and Demand Uncertainty on SA\&G Cost Stickiness. Islamic Business Researches Center. 
Anderson, M. C., Banker, R. D. and Janakiraman, S. N. (2003). Are Selling, General and Administrative Costs "Sticky"? Journal of Accounting Research, 41(1), 47-63.

Anderson, M. C., Lee, J. H. and Mashruwala, R. (2016). Cost Stickiness and Cost Inertia: A TwoDriver Model of Asymmetric Cost Behavior. Working Paper, doi: http://dx.doi.org/10.2139/ssrn.2599108

Atasoy, H., Banker, R. D. and Byzalov, D. (2014). Production Outsourcing and Demand Uncertainty. Available at: http://dx.doi.org/10.2139/ssrn.2647114

Balakrishnan, R. and Gruca. T. (2008). Cost stickiness and Core Competency: A Note. Contemporary Accounting Research, 25(4), 993-1006.

Baltagi, B. (2005). Econometric Analysis of Panel Data. John Wiley \& Sons.

Banker, R. D., Basu, S., Byzalov, D. and Chen, J. Y. (2016). The Confounding Effect of Cost Stickiness on Conservatism Estimates. Journal of Accounting and Economics, 61(1), 203-220.

Banker, R. and Byzalov. D. (2014). Asymmetric Cost Behavior. Journal of Management Accounting Research, 26(2), 43-79.

Banker, R. D., Byzalov, D. and Plehn-Dujowich, J. M. (2014). Demand Uncertainty and Cost Behavior. The Accounting Review, 89(3), 839-865.

Banker, R. D. and Johnston, H. H. (1993). An Empirical Study of Cost Drivers in the US Airline Industry. Accounting Review, 68(3), 576-601.

Calleja, K., Steliaros, M. and Thomas, D. C. (2006). A Note on Cost Stickiness: Some International Comparisons. Management Accounting Research, 17(2), 127-140.

Cheng, S., Jiang, W. and Zeng, Y. (2018). Does Access to Capital Affect Cost Stickiness? Evidence from China. Asia-Pacific Journal of Accounting \& Economics, 25 (1-2), 177-198.

Cohen, S., Karatzimas, S. and Naoum, V. C. (2017). The Sticky Cost Phenomenon at the Local Government Level: Empirical Evidence from Greece. Journal of Applied Accounting Research, 18(4), 445-463.

Fanti, L. and Meccheri, N. (2017). A Note on Managerial Delegation with Asymmetric and Convex Costs. Managerial and Decision Economics, 38 (3), 279-284.

Hartlieb, S. and Loy, T. R. (2017). Evidence on the Trade-off between Cost Stickiness and Income Smoothing. AAA 2017 Management Accounting Section (MAS) Meeting. Available at: http://dx.doi.org/10.2139/ssrn.2814309

Holzhacker, M., Krishnan, R. and Mahlendorf, M. D. (2015). Unraveling the Black Box of Cost Behavior: An Empirical Investigation of Risk Drivers, Managerial Resource Procurement, and Cost Elasticity. The Accounting Review, 90(6), 2305-2335.

Homburg, C., Hoppe, A., Nasev, J., Reimer, K. and Uhrig-Homburg, M. (2018). How Cost Stickiness Affects Credit Risk. Working Paper, Available At: https://ssrn.com/abstract=3232822

Horngren, C. T., Datar, S. M. and Rajan, M. V. (2012). Cost Accounting: A Managerial Emphasis (14th ed.). Upper Saddle River, NJ: Pearson/Prentice Hall.

Irvine, P. J., Park, S. S. and Yıldızhan, Ç. (2016). Customer-Base Concentration, Profitability, and the Relationship Life Cycle. The Accounting Review, 91(3), 883-906.

Ibrahim, A. E. A. (2015). Economic Growth and Cost Stickiness: Evidence from Egypt. Journal of Financial Reporting and Accounting, 13(1), 119-140.

Kallapur, S. and Eldenburg, L. (2005). Uncertainty, Real Options, and Cost Behavior: Evidence from Washington State Hospitals. Journal of Accounting Research, 43(5), 735-752. 
Koo, J. H., Song, S., and Paik, T. Y. (2015). Earning Management and Cost Stickiness. Advanced Science and Technology Letters, 84, 40-44.

Lee, J. H. (2018). Empirical Analysis of Asymmetric Cost Behavior (Doctoral dissertation). University of Calgary, Calgary, Canada.

Lee, J. Z. and Chiang, C. H. (2018). D\&O Insurance and SG\&A Cost Stickiness. Working Paper, Available At: http://dx.doi.org/10.2139/ssrn.3234103

Li, W. L. and Zheng, K. (2017). Product Market Competition and Cost Stickiness. Review of Quantitative Finance and Accounting, 49 (2), 283-313.

Liu, Y. and Lahiri, S. (2015). The Role of Foreign Competition and Cost Asymmetry in Partial Privatization. Working Paper, Available At: http://dx.doi.org/10.2139/ssrn.2691204.

Noreen, E. and Soderstrom, N. (1994). Are Overhead Costs Strictly Proportional to Activity? Evidence from Hospital Departments. Journal of Accounting and Economics, 17(1), 255278.

Noreen, E. and Soderstrom, N. (1997). The Accuracy of Proportional Cost Models: Evidence from Hospital Service Departments. Review of Accounting Studies 2(1), 89-114. 
